\title{
An Empirical Analysis Of Gender Role Stereotype Both At Work Place And Home
}

\author{
Nisrutha
}

\begin{abstract}
Gender and Gender stereotyping plays an influential role in one's personal and professional career too. The article tries to explore how gender effects gender stereotyping at both work place and home. The data had been collected from 100 faculty members from private universities located in Odisha, province of India through a questionnaire. Stratified random sampling technique was used for selecting respondents. Descriptive statistical methods are used for demographic data of the respondents. Cross tabulation is used to test the association between home stereotype score and workplace stereotype score. Statistical package for social sciences software is used for statistical analysis of the data. Results indicate that gender stereotyping still exists in the people with higher qualification also. The effect of gender stereotyping will be seen both at personal life and professional life. The people with no gender differentiation are more supportive than people with gender stereotyping.
\end{abstract}

Keywords : About Gender, Gender stereotype, Supportive .

\section{INTRODUCTION}

Organizations are considered as gendered institutions (Acker,2012). This is causing a glass ceiling effect in organizations. Though there is a drastic change in the scenario as women are having equal opportunities to work. But, the opportunities to grow are limited in both the professional environment and personal environment. Gender stereotype is one of the important element of determining success rate. While concentrating on gender element we cannot neglect gender stereotype as it gives much more important results. As, stereotypical expectations not only creates differences but it influences the way a women or men define themselves as well as treated by others (Ellemers, 2018).This paper tries to examine gender stereotyping in male vs female both in work place and at home. The author tries to interpret whether gender stereotyping exists in the individuals who are highly qualified.

\section{REVIEW OF LITERATURE}

\section{A.Gender and Gender Stereotype}

Gender research supports that women need to dedicate time for both work and family. Researchers furnished that organisations are implicitly gendered institutions(Foss, Woll, \& Moilanen, 2013). In most of the organisations men are occupied in higher positions (Foss et al, 2013). Ideas

Revised Manuscript Received on December 30, 2019.

* Correspondence Author

Nisrutha*, KSOM, KIIT Deemed to be university, Bhubaneswar, India.

(C) The Authors. Published by Blue Eyes Intelligence Engineering and Sciences Publication (BEIESP). This is an open access article under the CC BY-NC-ND license (http://creativecommons.org/licenses/by-nc-nd/4.0/) generated from women are not implemented in the organizations as compared to men's creative outputs (Lene, Kristin \& Mikko, 2013). Women in science and engineering are less motivated than female as their growth opportunities provided by organizations are less compared to men( Maskell-Pretz \& Hopkins, 1997). Gender stereotypes have both described and prescribed components which ordinarily advices about how they will act and how they should act ( Koenig, 2018). In general scientists are considered to be men as the ratio of men scientists are more compared to women." the stereotypic image of science and the scientist" is marked among the children (Markova,2014). The study of stereotypical differences expects not only to study the differences among gender but it actually reveals the way they define themselves and about others how they define them (Naomi Ellemers,2018). From the abundant literature it is evident that once goals for the life varies based on their socialization, opting a specific subject is also influenced by gender stereotype like scientists are men and beauticians are women by neglecting the fact that women are not nurtured or trained to take a profession in science rather cooking and beautician courses are treated as feminine oriented.

B.Gender stereotype and Culture

Culture is the grass root of upbringing gender stereotype into the society. In many cultures role of men and women are determined and this is how gender stereotypes are created and transferred from generations to generations. Women irrespective of countries from where they are spend most of the time on house hold activity though they are working women (Ellemers,2019).

Culture, class and race defines the roles of women in the society as entrepreneurship is seen as a masculine activity in the society(Adam and Anambane,2019). In Ghana (Sub Saharan African country) women are expected to be reserved, un ambitious and they must be caretakers of home (Adam and Anambane, 2019). Equal opportunities cannot be assured for men and women mostly in developing and underdeveloped countries as gender stereotype in embedded in these cultures. Wealth and educational opportunities are also unequally distributed in many countries. The transistors properties are unequally shared though many laws have came into existence but people neither take those laws into consideration and women in few societies won't try to express their opinion for equality. The religious beliefs of certain communities restricts women from joining work force such as police department( Salami,2007).

\section{C.Gender stereotype and Education}

From the literature review it is evident that gender differences are developed basically from the way boys and girls are raised and educated( Ellemers,2019).

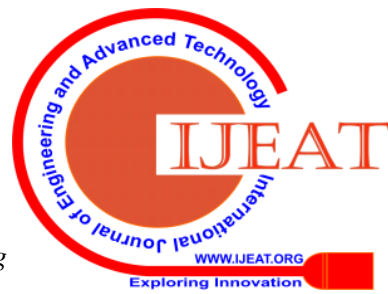


Though there is no difference between abilities of male and female students but ,gender stereotyping is projecting female students as less talented than male students in science education(Leslie et al, 2015 ; Ellemers,2019).Though the ratio of women enrolment in college education in India has improved to a larger extent (if required see the govt data). But still the gender role stereotype effects are influencing and making them confined to home. So, it effects their earning power as well as economic growth of the country. In Ireland also women employment rate is not proportional to women employed. In Nigeria women doesn't enrol much in science, mathematics and technical education compared to men(Salami, 2007).

\section{D.Gender stereotype and Profession}

Childhood aspirations and inspirations usually influence profession selection in later stages of life. A general stereotypes in public is seen in daily life such as cookery shows anchors would be females, crime reporters as men. Both the "children and adults cluster unknown individuals by their gender, even when this categorization is not releant to the situation and has no informational benefits" (Ellemers, 2019).Gender stereotype has negatively impacted the careers of women in entrepreneurship (Adom and Anambane,2019) but if they overcome these stereotypes and raise as entrepreneurs then it boosts their economic growth and as well as countries economic growth (De vita et al, 2014). Occupational roles in some of the fields are segregated majorly by men and in other fields major segregation is by women. Example: Police, army, navy jobs are mostly occupied by men. Example: Nursing, language teaching are mostly occupied by women. Women leave engineering jobs more frequently due to issues with work environment (Gordon, 2007). In this paper author tries to examine whether people belonging to same profession have different stereotype opinions or they don't have any stereotype either at work place or home.

\section{E.Effects of gender stereotype : Stereotype threat theory}

The stereotype threat theory basically explains the effect of negative stereotypes (Steel and Aranson, 1995). The stereotype threat theory underlines performance of people when they are working in social groups. The gender stereotyping affects innovative potential of employees (Foss et al, 2013). " Men and women may sometimes benefit and at times be adversely affected by gender " (Gil Aloni, 2013). The motivation levels of women entrepreneurial intentions got declined in the research work conducted by Gupta and Bhawe when they are exposed to common gender stereotypes. Because of several stereotypes women are negatively being effected in their professional life. Promotions, rewards and positions are given in favour of men though professional performance is similar.

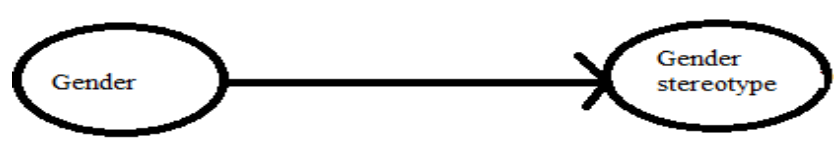

Figure 1b: conceptualframework of objective1

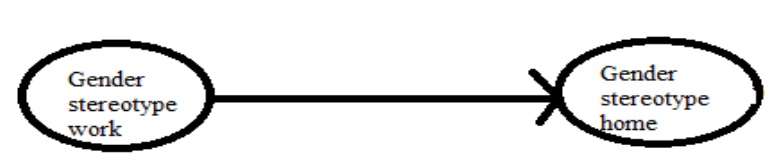

Figure 1: conceptual framework of the studyof objective2

\section{Hypotheses:}

Hypotheses for objective 1

Null hypothesis H0a: There is no association between gender and gender stereo type score at home.

Alternative hypothesis H1a: There is a positive association between gender and gender stereo type score at home.

Null hypothesis H0b: There is no association between gender and gender stereotype at work.

Alternative hypothesis H1b: There is a positive association between gender and gender stereo type score at work.

Hypotheses for objective 2

Null hypothesis H0c: There is no association between gender stereotype score at home and gender stereotype score at work. Alternative hypothesis H1c: There is a positive association between gender stereotype score at home and Gender stereotype score at work.

\section{METHOD}

\section{A.Sample}

Data were collected from 100 faculties of higher education institutions in Odisha, through a questionnaire survey in person and through Google forms. The total sample consisted of 85 assistant professors, 10 associate professors and 5 professors randomly. They were given brief information of the study.

\section{B.Measures}

Three independent measures were used in the study : gender, gender stereotype at home, gender stereotype at work place. Gender stereotype at home were taken from GRSS (Gender role stereotype scale) scale which consists of 8 items. In which certain tasks were given as statements and respondent need to select any one among the three choices from Men, Women, Both. This determines whether they are male stereotyped, female stereotyped or they do not have any stereotype.

Gender stereotype at workplace were taken from WAMS (women as managers scale) scale consists of 4 items High score (Agree, strongly agree) on these statements show that they are female stereotype and low score on these statements (Disagree, Strongly disagree) represents they are male stereotype. Alan 2017 scale which consists of 4 items these items response was collected on a 5 point Likert scale strongly disagree to strongly agree. High score on these statements represent male stereotype or female stereotype based on the statement and viceversa.

\section{C.Procedure}

Around 200 questionnaires were distributed among faculty members through mails and personally in their educational institutions in Odisha province of India. 
The faculty were briefly explained about the objective of research. After collecting their responses each questionnaire was scored and the scores obtained were used for data analysis. Out of 200 questionnaires distributed only 100 questionnaires were filled completely 50 were having many missing fields and 50 were unreturned. So, only 100 questionnaires were considered for final data analysis.

\section{RESULTS}

\section{Descriptive statistics}

From the frequency table provided below it can be seen that out of 100 respondents 35 were female and 65 were male respondents. We infer that in teaching profession also male are more in number compared to women hence this data goes with literature review that there is a need for eradication of stereotype in teaching also to encourage more number of women to work in this profession.

\section{Table I. Age of Respondent}

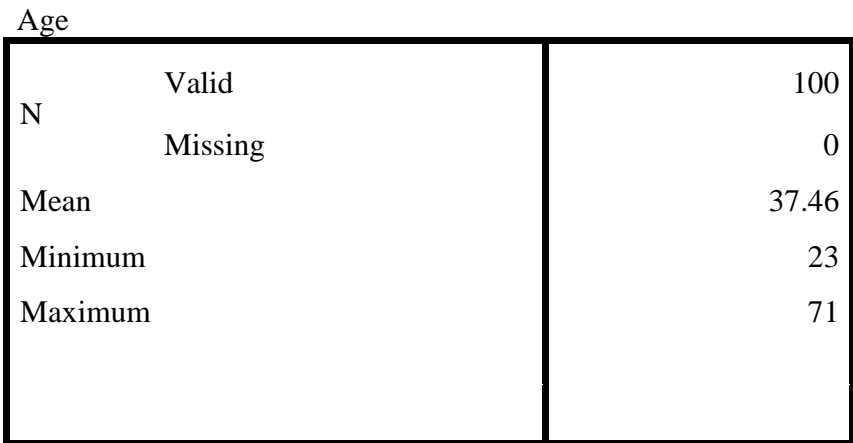

The minimum age of a respondent was 23 years and maximum age was 71 years

Table II. GENDER OF RESPONDENTS

\begin{tabular}{|r|r|r|r|r|}
\hline & Frequency & Percent & $\begin{array}{c}\text { Valid } \\
\text { Percent }\end{array}$ & $\begin{array}{c}\text { Cumulative } \\
\text { Percent }\end{array}$ \\
\hline Female & 35 & 35.0 & 35.0 & 35.0 \\
Valid Male & 65 & 65.0 & 65.0 & 100.0 \\
Total & 100 & 100.0 & 100.0 & \\
\hline
\end{tabular}

Out of 100 respondents 65 are male respondents and 35 are female respondents

From table 2 we can also interepret that more number of respondents are males though we followed random sampling necessity of improving employment opportunities for women is still having a gap.

In next table marital status of the respondents is shown majority of respondents are married

Table III.Maritalstatus Of Respondents

\begin{tabular}{|c|r|r|r|r|}
\hline & Frequency & Percent & $\begin{array}{r}\text { Valid } \\
\text { Percent }\end{array}$ & $\begin{array}{c}\text { Cumulative } \\
\text { Percent }\end{array}$ \\
\hline Divorced & 1 & 1.0 & 1.0 & 1.0 \\
Valid Married & 76 & 76.0 & 76.0 & 77.0 \\
Single & 15 & 15.0 & 15.0 & 92.0 \\
\hline
\end{tabular}

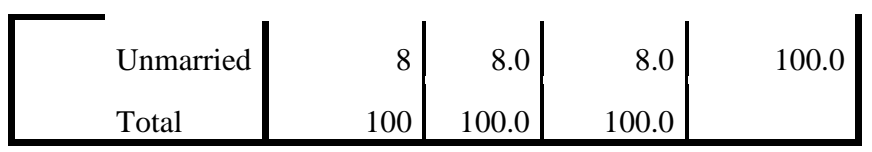

Out of 100 respondents 76 were married, 15 are single , 8 are unmarried and 1 is divorced.

Table IV. TOTALHOMESTEREOTYPESCORE

\begin{tabular}{|c|r|r|r|r|}
\hline & Frequency & Percent & \multicolumn{1}{c|}{$\begin{array}{c}\text { Valid } \\
\text { Percent }\end{array}$} & $\begin{array}{c}\text { Cumulative } \\
\text { Percent }\end{array}$ \\
\hline 0 & 36 & 36.0 & 36.0 & 36.0 \\
1 & 14 & 14.0 & 14.0 & 50.0 \\
2 & 11 & 11.0 & 11.0 & 61.0 \\
3 & 5 & 5.0 & 5.0 & 66.0 \\
4 & 6 & 6.0 & 6.0 & 72.0 \\
5 & 5 & 5.0 & 5.0 & 77.0 \\
6 & 6 & 6.0 & 6.0 & 83.0 \\
7 & 3 & 3.0 & 3.0 & 86.0 \\
8 & 2 & 2.0 & 2.0 & 88.0 \\
9 & 5 & 5.0 & 5.0 & 93.0 \\
10 & 4 & 4.0 & 4.0 & 97.0 \\
11 & 1 & 1.0 & 1.0 & 98.0 \\
12 & 1 & 1.0 & 1.0 & 99.0 \\
14 & 1.0 & 1.0 & 100.0 \\
Total & 100.0 & 100.0 & \\
\hline
\end{tabular}

Out of 100 respondents home stereotype score 36 respondents scored 0 it means they do not have any role stereotype related to home and rest of them are stereotyped either in 1 or more tasks.In table V. From 100 respondents 1 respondents do not have any role stereotype, 99 people have scored stereotype score either in one task or more than one questions out of 6 questions. So, majority of people are stereotyped. From this study we can say that though the sample is collected from highly educated people still there exists stereotype in their work life

Table V.Totalworkstereotypescore

\begin{tabular}{|r|r|r|r|r|}
\hline & Frequency & Percent & \multicolumn{1}{|c|}{$\begin{array}{c}\text { Valid } \\
\text { Percent }\end{array}$} & \multicolumn{2}{|c|}{$\begin{array}{c}\text { Cumulative } \\
\text { Percent }\end{array}$} \\
\hline .00 & 1 & 1.0 & 1.0 & 1.0 \\
3.00 & 1 & 1.0 & 1.0 & 2.0 \\
4.00 & 8 & 8.0 & 8.0 & 10.0 \\
5.00 & 1 & 1.0 & 1.0 & 11.0 \\
6.00 & 1 & 1.0 & 1.0 & 12.0 \\
7.00 & 1 & 1.0 & 1.0 & 13.0 \\
8.00 & 7 & 7.0 & 7.0 & 20.0 \\
9.00 & 5 & 5.0 & 5.0 & 25.0
\end{tabular}




\begin{tabular}{|r|r|r|r|r|}
\hline 10.00 & 10 & 10.0 & 10.0 & 35.0 \\
11.00 & 7 & 7.0 & 7.0 & 42.0 \\
12.00 & 17 & 17.0 & 17.0 & 59.0 \\
13.00 & 8 & 8.0 & 8.0 & 67.0 \\
14.00 & 16 & 16.0 & 16.0 & 83.0 \\
15.00 & 4 & 4.0 & 4.0 & 87.0 \\
16.00 & 6 & 6.0 & 6.0 & 93.0 \\
17.00 & 1 & 1.0 & 1.0 & 94.0 \\
18.00 & 5 & 5.0 & 5.0 & 99.0 \\
19.00 & 1 & 1.0 & 1.0 & 100.0 \\
Total & 100 & 100.0 & 100.0 & \\
\hline
\end{tabular}

Based on the objectives of the study the main issue of the paper is to findout asscoaition between gender and workstereotype, gender and home stereotype. In table 6 we will see crosstabulation to find out association between gender and work stereotype using chisquare.

Table VI.Gender * newworkstereotypescore

\section{Crosstabulation}

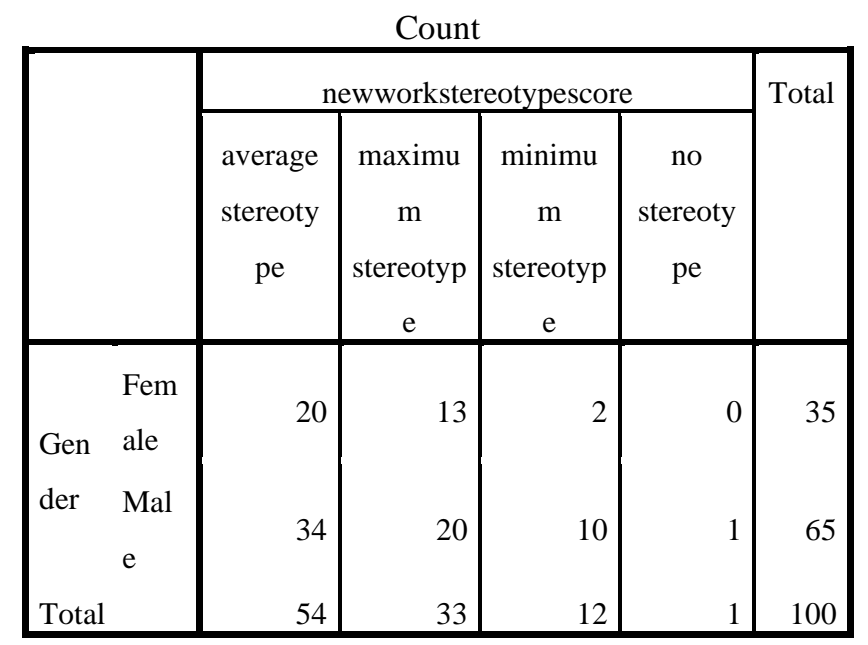

We can interpret from cross tabulation table between gender and work stereotype score clearly that all female respondents are scoring some stereotype score, in the same manner all males also scored some stereotype score expect 1 respondent who scored 0 that is no stereotype.

Table VII.Chi-Square Tests Of Gender * work stereotype

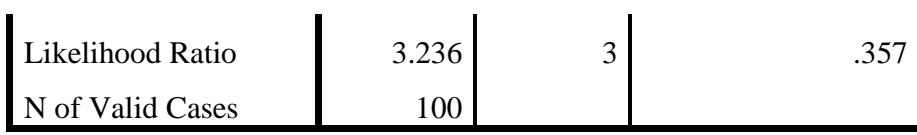

a. 3 cells (37.5\%) have expected count less than 5 . The minimum expected count is .35 .

From pearson chisquare table $\mathrm{p}$-value $=0.442$ at degree of freedom 3 since it is greater than 0.05 hence gender and work stereotype are not positively associated with eachother.

So gender may not be influencingwork stereotype .

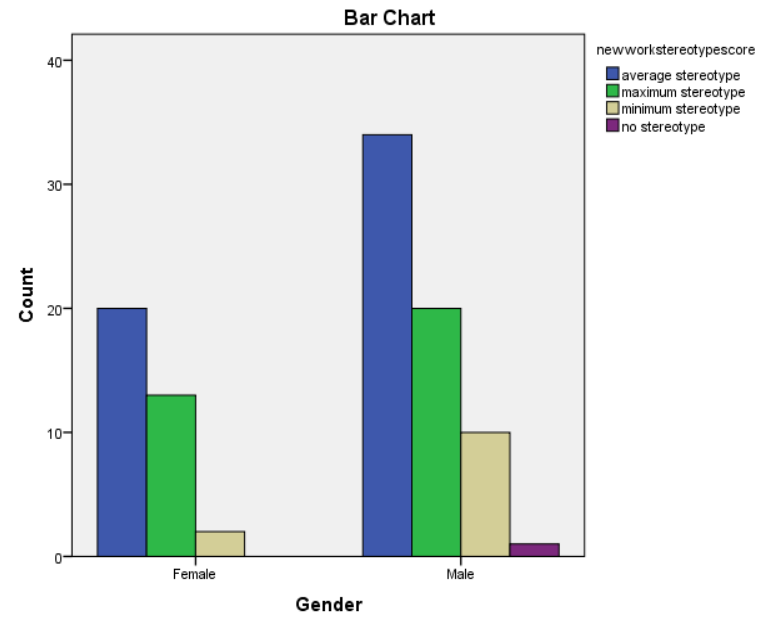

Figure. 2 Work stereotype score

From the above graph we can interpret the data as follows Male and Female respondents both have scored more average stereo type score.

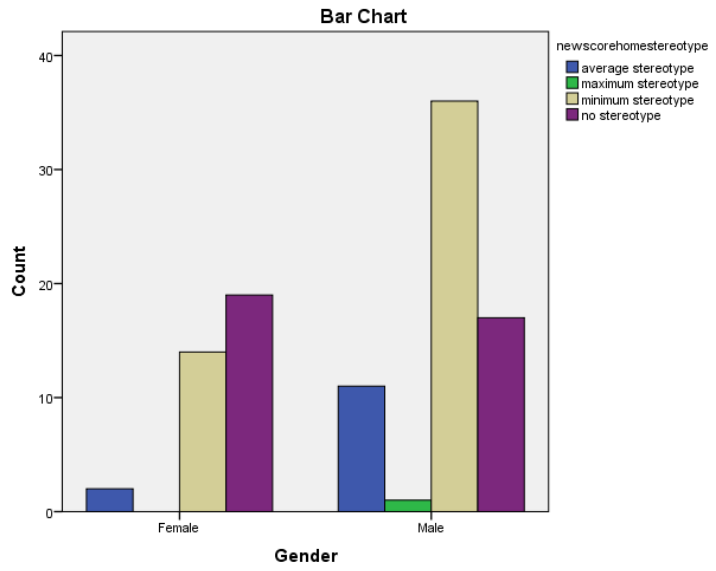

Figure. 3 Home stereotype score

From the above graph we can interpret that females did not score maximum stereotype score mostof the females have no sfereotype.In males most of them have minimum stereotype sfereotyp

\begin{tabular}{|l|c|c|c|}
\hline & Value & df & $\begin{array}{c}\text { Asymp. Sig. } \\
\text { (2-sided) }\end{array}$ \\
\hline Pearson Chi-Square & $2.690^{\mathrm{a}}$ & 3 & .442 \\
\hline
\end{tabular}

Table VIII.Gender * newscorehomestereotype Crosstabulation

Count 


\begin{tabular}{|rr|r|r|r|r|r|}
\hline & average stereotype & $\begin{array}{c}\text { maximum } \\
\text { stereotype }\end{array}$ & minimum stereotype & no stereotype & \\
\hline \multirow{2}{*}{ Gender } & Female & 2 & 0 & 14 & 19 & 35 \\
& Male & 11 & 1 & 36 & 17 & 36 \\
Total & 13 & 1 & 50 & 100 \\
\hline
\end{tabular}

From the gender * home stereotype cross tabulation 19 other respondents have minimum or average stereotype females are not stereotyped ,17 males are not stereotyped. score.

Table IX.Chi-Square Tests Of Gender * Homestereotype

\begin{tabular}{|l|r|r|r|}
\hline & \multicolumn{1}{|c|}{ Value } & df & $\begin{array}{c}\text { Asymp. Sig. } \\
\text { (2-sided) }\end{array}$ \\
\hline Pearson Chi-Square & $8.815^{\mathrm{a}}$ & 3 & .032 \\
Likelihood Ratio & 9.236 & 3 & .026 \\
N of Valid Cases & 100 & & \\
\hline
\end{tabular}

Table X. newscorehomestereotype * newworkstereotypescore Crosstabulation

\begin{tabular}{|c|c|c|c|c|c|c|}
\hline \multicolumn{7}{|c|}{ Count } \\
\hline & & \multicolumn{4}{|c|}{ newworkstereotypescore } & \multirow[b]{2}{*}{ Total } \\
\hline & & $\begin{array}{l}\text { Average } \\
\text { stereotype }\end{array}$ & $\begin{array}{c}\text { Max } \\
\text { stereotype }\end{array}$ & $\begin{array}{c}\text { Min } \\
\text { stereotype }\end{array}$ & $\begin{array}{c}\text { No } \\
\text { stereotype }\end{array}$ & \\
\hline \multirow{5}{*}{ newscorehomestereotype } & $\begin{array}{c}\text { average } \\
\text { stereotype }\end{array}$ & 5 & 5 & 3 & 0 & 13 \\
\hline & $\begin{array}{l}\text { maximum } \\
\text { stereotype }\end{array}$ & 0 & 1 & 0 & 0 & 1 \\
\hline & stereotype & 25 & 19 & 6 & 0 & 50 \\
\hline & $\begin{array}{c}\text { no } \\
\text { stereotype }\end{array}$ & 24 & 8 & 3 & 1 & 36 \\
\hline & & 54 & 33 & 12 & 1 & 100 \\
\hline
\end{tabular}

a. 3 cells $(37.5 \%)$ have expected count less than 5 . The miniminfabulation between home stereotype(13 average, max 1 , expected count is . 35 .

From chi-square table we can interpret that p-value is 0.032 which is less than 0.05 so there is a positive association between gender and gender stereotype at home.

From the above statistical data we can conclude that gender influences the gender stereotype role at home. It means gender plays a major role in stereotype at home as few roles are ultimately differentiated based on the gender (54 average, 33 maximum, 12 minimum and 1 no stereotype).

Table XI.Chi-Square Tests Of Homestereotype * Workstereotype

\begin{tabular}{|l|r|r|r|}
\hline & \multicolumn{1}{|c|}{ Value } & df & Asymp. Sig. (2-sided) \\
\hline Pearson Chi-Square & $9.093^{\mathrm{a}}$ & 9 & .429 \\
Likelihood Ratio & 9.435 & 9 & .398 \\
N of Valid Cases & 100 & & \\
\hline
\end{tabular}

a. 10 cells (62.5\%) have expected count less than 5 . The minimum expected count is .01 .

From chi-square table it can be interpreted that p-value at degree of freedom 9 is 0.429 which is greater than 0.05 so there is no positive association between home stereotype score and work stereotype score. 


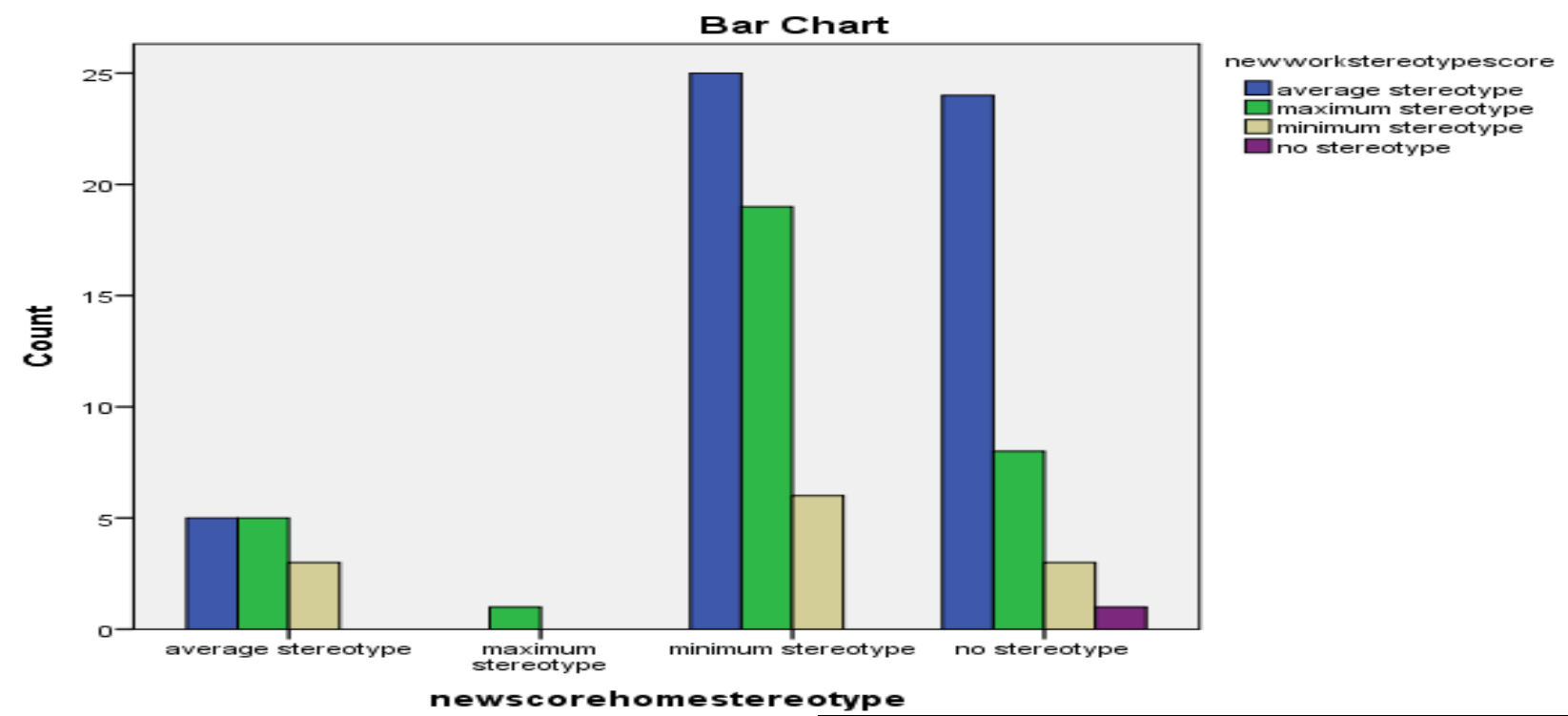

Results Summarized

Table 12. Analysis of Hypothesis results

\begin{tabular}{|l|l|l|}
\hline \multicolumn{1}{|c|}{ Hypothesis } & Null hypothesis & Alternative \\
Statement & accepted & hypothesis \\
\hline Null hypothesis & & Accepted \\
H0a: There is no & & \\
association gender \\
between gen gereo \\
and gender stereo \\
type score at \\
home. \\
$\begin{array}{l}\text { Alternative } \\
\text { hypothesis H1a: } \\
\text { There is positive } \\
\text { association gender } \\
\text { between gender } \\
\text { and gender stereo } \\
\text { type score at } \\
\text { home. }\end{array}$
\end{tabular}

Null hypothesis

H0c: There is no association

between gender stereotype score at home and gender stereotype score at work.

Alternative hypothesis H1c: There is a positive association

between gender stereotype score at home and Gender stereotype score at work.

\section{Accepted}

\section{CONCLUSION AND DISCUSSION}

The author in this paper tries to identify whether gender has any impact on gender stereo type score either at home or at work place. From the respondents data after statistical analysis of the data it is clear that gender and gender stereotype at home roles are positively related. Though the respondents of this study are highly educated people still they are stereotyped in home roles. In further research we try to focus to work out on parameters to reduce stereotypes at home roles. From the data it is evident that there is no positive association between work stereotype score and home stereotype score. It means people who are scoring high at home stereotype need not have score high in work place stereotype score. Finally we want to conclude that people are more stereotyped at home place than at work place especially in the roles like taking care of children or cooking mostly respondents have selected women instead of other two options men or both. So, still home role stereotype exists though women works or men allow them to work but few roles are still women roles. 


\section{REFERENCES}

1. Acker, J. (2012), "Gendered organisations and intersectionality: problems and possibilities ", Equality, Diversity and Inclusion: An International Journal, Vol. 31 No.3, pp. 214-224.

2. Adom, K., \& Anambane, G. (2019). Understanding the role of culture and gender stereotypes in women entrepreneurship through the lens of the stereotype threat theory. Journal of Entrepreneurship in Emerging Economies, ahead-of-print(ahead-of-print). https://doi.org/10.1108/JEEE-07-2018-0070

3. Aloni, G., \& Syna Desivilya, H. (2013). Eve's emancipation or lingering subordination to Adam? International Journal of Conflict Management, Volume $24 \quad$ No.3, 284-306. https://doi.org/DOI 10.1108/IJCMA-10-2011-007

4. Ellemers, N. (2017). Gender Stereotypes. Annual review ofpsychology.26.

5. Gordon, H. S. (2007). RUTGERS THE STATE UNIVERSITY OF NEW JERSEY, 61.

6. Foss, L., Woll, K., \& Moilanen, M. (2013). Creativity and implementations of new ideas: Do organisational structure, work environment and gender matter? International Journal of Gender and Entrepreneurship, 5(3), 298-322. https://doi.org/10.1108/IJGE-09-2012-0049

7. Lene, F.; Kristin, W.; Mikko, M.(2013)." Creativity and Implementation of New Ideas: Do organisational structure, Work Environment and Gender Matter ?", International Journal of Gender and Entrepreneurship, Vol. 5, No. 3, p. 298-322.

8. Mills, M. J., Culbertson, S. S., Huffman, A. H., \& Connell, A. R. (2012). Assessing gender biases: Development and initial validation of the gender role stereotypes scale. Gender in Management: An International Journal, 27(8), 520-540. https://doi.org/10.1108/17542411211279715

9. O. Salami, S. (2007). Influence of culture, family and individual differences on choice of gender-dominated occupations among female students in tertiary institutions. Women in Management Review, Vol. 22(8), 650-665. https://doi.org/DOI 10.1108/09649420710836326

10.Steele, C.M. and Aranson, J. (1995), "Stereotype threat and the intellectual test performance of African Americans", Journal of Personality and Social Psychology, Vol. 69 No. 5, PP. 797.

\section{AUTHORS PROFILE}

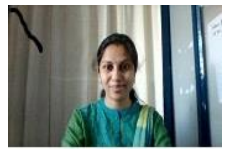

Nisrutha is currently doing her $\mathrm{PhD}$ research in the field of HRM in KSOM Kiit deemed to be university ,She did her MBA from Osmania university and B.Tech from JNTU Hyderabad. She has qualified Ugc NET in management.Her research interest lies in the areas of Gender studies, HRM, OB, Creativity in academics. She published her papers in reputed conferences and journals in national and international level. 